\title{
Pozytywne i negatywne konsekwencje szarej strefy postrzeganej jako,,zręczność podatkowa” podmiotów gospodarczych i gospodarstw domowych
}

\section{POSITIVE AND NEGATIVE CONSEQUENCES OF THE GRAY ECONOMY "TAX DEXTERITY" OF BUSINESS ENTITIES AND HOUSEHOLDS}

\begin{abstract}
Artykut podejmuje problematykę szarej strefy. W pierwszej części została ujęta definicja szarej strefy $w$ kontekście oszustw podatkowych oraz skala zjawiska $w$ Polsce. $W$ kolejnych przedstawione zostaty negatywne $i$ pozytywne skutki szarej strefy wymieniane $w$ literaturze przedmiotu. W trzecim punkcie zaprezentowano fragmenty badań ankietowych dotyczacych opisywanego problemu badawczego. W ostatniej czesści publikacji wskazano dziatania instytucjonalne oddziałujace na rozmiary szarej strefy $w$ Polsce. Podstawowym celem niniejszej publikacji jest prezentacja pozytywnych i negatywnych konsekwencji występowania szarej strefy rozumianej jako oszustwo podatkowe $i$ wskazania, które z nich przeważaja w ocenie subiektywnej badanych podmiotów gospodarczych $i$ gospodarstw domowych. W ramach artykułu zostały także zasygnalizowane rozwiazania instytucjonalne majace na celu ograniczyć badane zjawisko. Realizacja celu wymagała wykorzystania metod opisowo-statystycznych, a w szczególności analizy ksztattowania się zakresu gospodarki nieobserwowalnej w Polsce i wybranych krajach. W artykule postużono się badaniami ankietowymi z lat 2010-2019, w celu dokonania próby jakościowej oceny skutków zjawiska szarej strefy.
\end{abstract}

Słowa kluczowe: szara strefa, gospodarka nieobserwowalna, oszustwa podatkowe, skutki szarej strefy

JEL Codes: H21, H24, H26, H83

\section{Wprowadzenie}

Szara strefa jest uniwersalnym zjawiskiem występującym w różnym zakresie we wszystkich państwach świata. Ocenia się, że średnio w krajach OECD około 18\% PKB jest wytwarzana $\mathrm{w}$ gospodarce nieobserwowalnej, a wskaźnik ten w państwach rozwijających się przekracza nawet $40 \% \mathrm{PKB}^{1}$. Skutki szarej strefy najczęściej rozpatruje się w kontekście negatywnym, choć może spotkać się z pozytywnymi konsekwencjami opisywanego zjawiska.

\footnotetext{
${ }^{1}$ F. Schneider, A. Buehn, Shadow Economy: Estimation Methods, Problems, Results and Open questions, Open Economics 2018, 1:1-29, s. 22; DOI 10,1515/openec-2017-0001
} 
Podstawowym celem niniejszej publikacji jest prezentacja pozytywnych i negatywnych konsekwencji występowania szarej strefy rozumianej jako oszustwo podatkowe i wskazania, które $\mathrm{z}$ nich przeważają $\mathrm{w}$ ocenie subiektywnej badanych podmiotów gospodarczych i gospodarstw domowych. W ramach artykułu zostały także zasygnalizowane rozwiązania instytucjonalne mające na celu ograniczać badane zjawisko. Realizacja celu wymagała wykorzystania metod opisowo-statystycznych, a w szczególności analizy kształtowania się zakresu gospodarki nieobserwowalnej w Polsce i wybranych krajach. W artykule posłużono się własnymi badaniami ankietowymi z lat 2010-2019, w celu dokonania próby jakościowej oceny skutków zjawiska szarej strefy.

W pierwszej części artykułu została ujęta definicja szarej strefy w kontekście oszustw podatkowych oraz skala zjawiska w Polsce. W kolejnych przedstawione zostały negatywne i pozytywne skutki szarej strefy wymieniane w literaturze przedmiotu. W trzecim punkcie zaprezentowano badania ankietowe dotyczące opisywanego problemu badawczego. W ostatniej części publikacji wskazano działania instytucjonalne oddziałujące na rozmiary szarej strefy w Polsce.

\section{Pojęcie i skala szarej strefy}

Szara strefa jest pojęciem niejednoznacznym, gdyż w literaturze przedmiotu można spotkać się z wieloma, często zbliżonymi, ale także wykluczającymi się definicjami. Różnorodność ujęć definicyjnych wynika z różnych celów badaczy tego zjawiska oraz zróżnicowania systemów społeczno-ekonomicznych poddawanych obserwacji. ${ }^{2}$ Najpopularniejszym jest pogląd, iż jest to działalność nie podlegająca rejestracji w rachunkach narodowych. Niemal równie często podkreśla się, iż jest to aktywność, która sprowadza się do uchylania się od opodatkowania. Stąd szara strefa przez wielu finansistów nazywana jest ,zręcznością podatkową” czy nadużywaniem prawa podatkowego. ${ }^{3} \mathrm{Na}$ takim ujęciu skoncentrowano się w niniejszej publikacji.

Według E.L. Feige szara strefa to część działań ekonomicznych, z których dochody są wyłączone spod regulacji prawnych, opodatkowania oraz obserwacji organów urzędowych. Wszystkie te działania mają jedną wspólną cechę - osoby w nie zaangażowane dążą do ukrycia przed organami rządowymi osiągniętych dochodów. ${ }^{4}$ D. Cassel i A. Caspers przez pojęcie gospodarki nieoficjalnej rozumieją te wszystkie formy aktywności gospodarczej, które nie są uregulowane przepisami prawnymi oraz nie podlegają opodatkowaniu ${ }^{5}$. Podobnie F. Schneider używa terminu szara strefa dla określenia aktywności rynkowej polegającej na produkcji niezakazanych produktów, ukrytą przed kontrolą publiczną, w celu uniknięcia odprowadzania podatków, świadczeń społecznych czy innych regulacji ${ }^{6}$. S. Pozo z kolei definiuje ją jako przedsięwzięcia

${ }^{2}$ B. Mróz, Metody pomiaru gospodarki nieoficjalnej, „Ekonomista”, nr 1, 2001, s. 93.

3 J.C. Martinez, La fraude fiscale, Paris 1984, s. 11. [Za:] M. Kalinowski, Granice legalności unikania opodatkowania w polskim systemie podatkowym, TNOiK, Toruń 2001, s. 24.

${ }^{4}$ E.L. Feige, The underground economy. Tax evasion and information distortion, Cambridge University Press, 1989 , s. 2.

${ }^{5}$ D. Cassel, A. Caspers, Was ist Schattenwirtschaft? Begriff und Erscheinungsformen der Sekond Economy, Wistschaftswissenschaftliches Studium, Heft 1, 1984, s. 1-7.

${ }^{6}$ F. Schneider, C. Williams, The Shadow Economy, Institute of Economic Affairs, Profile Books, Ltd. - Hobbs the Printers, London 2013, s. 25. 
gospodarcze, które są dokonywane poza normami prawa ${ }^{7}$. L. Balcerowicz zaznacza, że szara strefa obejmuje nieopodatkowane dochody osiągane przy produkcji legalnych dóbr i usług. Wiąże się ona z niepłaceniem podatków, chociaż chęć ich uniknięcia nie musi być jedynym motywem działania ${ }^{8}$. Na podobną cechę zwrócili uwagę Z. Rajewski i L. Zienkowski, którzy podkreślają, że celem podmiotów funkcjonujących w sektorze nieformalnym jest świadome unikanie płacenia świadczeń pieniężnych na rzecz państwa. ${ }^{9}$ Również K. Dzierżawski definiuje zjawisko szarej strefy jako głównie polegające na uchylaniu się od płacenia podatków ${ }^{10}$.

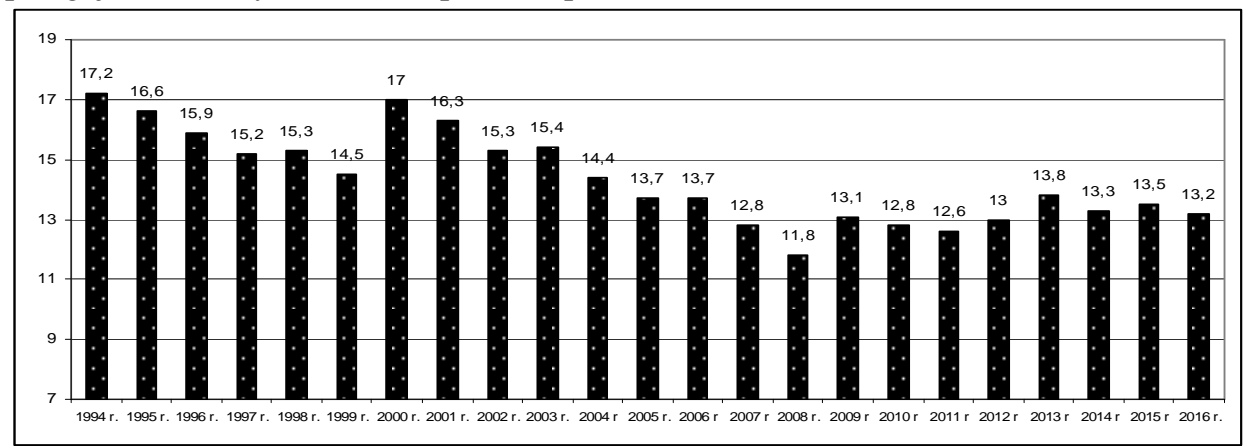

Rysunek 1. Szara strefa w Polsce według GUS w latach 1994-2016 (w \%)

Źródło: Opracowanie własne na podstawie: Rachunki narodowe wg sektorów i podsektorów instytucjonalnych, GUS z lat 1995-2018.

Nie tylko definicja szarej strefy jest nieprecyzyjna. Podobnie szacunki tego zjawiska, z uwagi na jego „,nieuchwytny” charakter są trudno mierzalne. W najdłuższym horyzoncie czasowym szacunki rozmiaru gospodarki nieobserwowalnej dokonywane są przez GUS. Rysunek 1. ilustruje udział szarej strefy w tworzeniu PKB w latach 1994-2016. W 1994 roku udział ten kształtował się na najwyższym poziomie 17,2\%, po czym zaczął systematycznie spadać do 2000 r., kiedy wzrósł ponownie do 17\%. W 2008 r. obniżył się do najniższego poziomu, szacowanego na $11,8 \%$ PKB. W kolejnych latach, wraz z spowolnieniem gospodarczym, będącym skutkiem kryzysu subprime, wskaźnik wzrósł o 1-2 pkt. proc. W latach 2012-2015 udział szarej strefy w polskiej gospodarce wynosił średnio 13,4\%. Najniższym poziomem odznaczał się 2012 rok (13,0\%), a najwyższym 2013 rok $(13,8 \%)^{11}$. W 2016 roku udział gospodarki nieobserwowalnej oszacowano na 13,2 \% PKB, z czego szara strefa w jednostkach zarejestrowanych wynosiła $10,8 \%$, z tytułu wykonania pracy nierejestrowanej $2,1 \%$, natomiast działalność nielegalna (sutenerstwo, narkotyki, przemyt papierosów) oszacowano na $0,3 \% \mathrm{PKB}^{12}$

\footnotetext{
${ }^{7}$ S. Pozo, Exploring the Underground Economy. Studies of Illegal and Unreported Activity, W.E. Upjohn Institute for Employment Research, Kalamazoo 1996, s. 156.

${ }^{8}$ L. Balcerowicz, Socjalizm, kapitalizm, transformacja, Szkice z przełomu epok, PWN, Warszawa 1997.

${ }^{9}$ Z. Rajewski, L. Zienkowski, Szara gospodarka w systemie rachunków narodowych, [w:] Szara gospodarka $w$ Polsce. Rozmiary, przyczyny, konsekwencje, ZBSE GUS i PAN, Zeszyt 233, Warszawa 1996, s. 13.

${ }^{10}$ K. Dzierżawski, Krótki kurs ekonomii praktycznej, Wydawnictwo Zysk I Spółka, Warszawa 2006, s. 85.

${ }^{11}$ Rachunki narodowe według sektorów i podsektorów instytucjonalnych $w$ latach 2012-2015, GUS, Warszawa 2017, s. 267.

${ }^{12}$ Rachunki narodowe według sektorów i podsektorów instytucjonalnych w latach 2013-2016, GUS, Warszawa 2018, s. 281 i nast.
} 
$\mathrm{Na}$ nieco wyższym poziomie szarą strefę oblicza Instytut Prognoz i Analiz Gospodarczych (IPAG), w ocenie którego całkowita wartość gospodarki nieobserwowalnej w 2019 roku wyniesie 242 mld PLN, co stanowić będzie 17,2\% PKB (w 2016 r. $-19,0 \%, 2017$ r. $-18,7 \%$ PKB, w 2018 r. - 18,0\%) ${ }^{13}$. Natomiast najwyższe wskazania widoczne są $\mathrm{w}$ dorobku Friedricha Schneidera, specjalizującego się w badaniach nad szarą strefą w oparciu o metodę MIMIC (Multiple Indicators Multiple Causes). Oblicza on udział gospodarki nieoficjalnej w PKB w Polsce na poziomie 22,2\% PKB w 2017 r. $(22,7 \% \text { w } 2016 \text { r.; 23,3\% w } 2015 \text { r. })^{14}$.

\section{Negatywne skutki występowania szarej strefy}

Istnienie szarej strefy w ocenie B.S Freya i F. Schneidera stwarza wiele następstw negatywnych, które można ujać w czterech grupach ${ }^{15}$ :

- ocena warunków ekonomicznych i socjalnych obywateli jest niewiarygodna, gdyż szara strefa fałszuje statystyki,

- utrata dochodów podatkowych, gdyż działalność nieoficjalna unika opodatkowania,

- szara strefa osłabia więzi społeczne,

- sprzyja niewłaściwej relacji pomiędzy podatnikami a rządem.

Natomiast C. Elgin i B.R. Uras na podstawie przeprowadzonych badań wskazują, iż szara strefa skutkuje szeregiem negatywnych zjawisk, takich jak: zwiększone zadłużenie, wyższe koszty obsługi długu publicznego, a także podwyższone ryzyko niestabilności finansowej państwa ${ }^{16}$.

Do najistotniejszych ujemnych skutków makroekonomicznych funkcjonowania gospodarki nieformalnej należą niewątpliwie zmniejszone wpływy do budżetu państwa spowodowane unikaniem płacenia podatków i składek na ubezpieczenie społeczne przez przedsiębiorców i osoby fizyczne ${ }^{17}$. Luka w przychodach budżetowych wynikająca z funkcjonowania gospodarki nieoficjalnej może być jedną $\mathrm{z}$ przyczyn deficytu budżetowego. Ten $\mathrm{z}$ kolei może się wiązać $\mathrm{z}$ inflacją, szczególnie gdy mamy do czynienia $\mathrm{z}$ pełnym wykorzystaniem zdolności produkcyjnych $\mathrm{w}$ gospodarce. ${ }^{18}$ Zmniejszenie dochodów podatkowych ma swoje dalsze konsekwencje w postaci bardziej restrykcyjnej polityki fiskalnej ${ }^{19}$.

Negatywnego oddziaływania szarej strefy na gospodarkę nie można mierzyć tylko skalą utraconych wpływów podatkowych. Jej istnienie powoduje złe adresowanie

${ }^{13}$ J. Fundowicz, K. Łapiński, B. Wyżnikiewicz, D.Wyżnikiewicz, Szara strefa 2019, Instytut Prognoz i Analiz Gospodarczych, Warszawa marzec 2019, s. 24.

${ }^{14}$ L. Medina, F. Schneider, Shadow Economies Around the World: What Did We Learn Over the Last 20 Years?, WP/18/17, International Monetary Fund, Styczeń 2018, s. 18, 66 i nast.

15 B.S. Frey, F. Schneider, Ekonomika gospodarki nieformalnej, [w:] A. Karwińska, A.Surdeja (red.), Wokót zagadnień gospodarki nieformalnej, Wydawnictwo AE w Krakowie, Kraków 2004, s. 15.

${ }^{16}$ C. Elgin, B.R. Uras, Public debt, sovereign default risk and shadow economy, „Journal of Financial Stobility", Np 9, 2013, s. 19.

${ }^{17}$ J.E. Stiglitz, Ekonomia sektora publicznego, PWN, Warszawa 2010, s. 854

${ }^{18}$ W. Herrer, W. Sadowski, Wptyw ,szarej strefy” na makroproporcje gospodarki narodowej, [w:] Szara gospodarka w Polsce. Rozmiary, przyczyny, konsekwencje, Zakład Badań Statystyczno-Ekonomicznych GUS i PAN, z. 233, Warszawa 1996, s. 34-35.

19 J. Fundowicz, K. Łapiński, B. Wyżnikiewicz, Szara strefa 2018, Instytut Prognoz i Analiz Gospodarczych, Warszawa marzec 2018, s. 9. 
pomocy socjalnej dla osób bezrobotnych lub o niskich dochodach. Zwiększają się wydatki na programy socjalne. Wbrew celom państwa obejmują one również osoby o większych, ale ukrytych dochodach. ${ }^{20} \mathrm{~W}$ rezultacie publiczne środki są nieracjonalnie wydatkowane i ograniczają możliwość uzyskania pieniędzy osobom rzeczywiście potrzebującym pomocy. Szara strefa przyczynia się także do powstawania tzw. efektu gapowicza. Polega on na ty, że osoby, które niepłacą podatków korzystają z usług finansowanych ze źródeł budżetowych na równi z uczciwymi płatnikami świadczeń fiskalnych. Przykładem takich usług może być opieka zdrowotna bądź edukacja ${ }^{21}$.

Ponadto, jeśli znacząca część przedsiębiorców i gospodarstw domowych uchyla się przed płaceniem podatków, do budżetu państwa wpływa zbyt mało środków. To z kolei wymusza podwyżki obciążeń fiskalnych dla tych, którzy płacą - i w konsekwencji, wyższe podatki skłaniają kolejne podmioty do ucieczki w szarą strefę.

$\mathrm{Z}$ sektorem nieformalnym związana jest też nieuczciwa konkurencja. Podmioty legalnie działające $\mathrm{w}$ niektórych segmentach rynku nie mają szans w konkurencji z przedsiębiorstwami działającymi na większą skalę w szarej strefie. Niższe koszty pozwalają ustalać niższe ceny, co może wydatnie utrudniać przedsiębiorstwom działającym legalnie pełne wykorzystanie rozporządzalnych zdolności produkcyjnych i wpędzać je $\mathrm{w}$ trudności płatnicze wobec organów administracji państwowej oraz kontrahentów. Fakt ten często powoduje paradoksalne zjawisko przymusu działania w szarej strefie. Firmy działające legalnie, chcąc utrzymać się na rynku, zostają zmuszone do działalności w sektorze nieformalnym. ${ }^{22}$ Ponadto przedsiębiorstwa działające legalnie ponoszą straty wynikające $\mathrm{z}$ podrabiania towarów. Nieformalna produkcja wiąże się także z pojawieniem się na rynku produktów dóbr i usług o niższej jakości $^{23}$, niespełniających powszechnie obowiązujących norm ${ }^{24}$.

Jedną $\mathrm{z}$ form szarej strefy, także związaną $\mathrm{z}$ ukrywaniem dochodów do opodatkowania jest nierejestrowane zatrudnienie, związane $\mathrm{z}$ ryzykiem zarówno pracownika, jak i pracodawcy. Pracodawca narażony jest na poniesienie kosztów związanych z opłaceniem kar administracyjnych, a także ryzyko odpowiedzialności za ewentualne wypadki przy pracy i choroby zawodowe na zasadach ogólnych, tj. według powszechnie obowiązujących przepisów prawa cywilnego, a nie według przepisów prawa pracy, które $\mathrm{z}$ reguły określają zryczałtowane stawki odpowiedzialności majątkowej za wyrządzoną szkodę. ${ }^{25}$

Nierejestrowane zatrudnienie jest w dłuższej perspektywie niekorzystne dla pracownika, który krótkookresowo wprawdzie zyskuje, gdyż unika płacenia podatku

${ }^{20}$ T. Kowalik (red.), Nierówni i równiejsi, Fundacja Innowacja, Warszawa 2002, s. 226

${ }^{21}$ S. Szarek, D. Okliński, Czynniki wptywające na akceptację szarej strefy w spoteczeństwie, Zeszyt Naukowe Uniwersytetu Przyrodniczo-Humanistycznego w Siedlcach, Seria Administracja I Zarządzanie, nr 109/2016, s. 94

${ }^{22}$ T. Chrościcki, M. Misiak, Szara strefa, „Nasz Rynek Kapitałowy”, nr 10, październik 2005, s. 66.

${ }^{23}$ T. Piecuch, E. Szczygieł, Przedsiębiorczość szarej strefy, „Roczniki Ekonomii i Zarządzania”, Tom 10 (46), nr 2, 2018, s.98. DOI:http://dx.doi.org/10.18290/reiz.2018.10.2-6

${ }^{24}$ K. Górka, M. Łuszczyk, Gospodarka nieobserwowalna w Polsce i na świecie, Studia i Prace Wydzialu Nauk Ekonomicznych i Zarządzania, Uniwersytet Szczeciński, nr 41, t. 2. 2015, s.223. DOI:10.18276/SIP.2015.44/2-19

25 A. Świątkowski, Międzynarodowa polityka społeczna wobec świadczacych pracę $w$ nieformalnej gospodarce, „Polityka Społeczna”, nr 4, 2003, s. 2. 
dochodowego, jednak długookresowo traci, gdyż nie przysługują mu standardowe świadczenia pracownicze (chorobowe, wypadkowe, emerytalne).

\section{Pozytywny aspekt funkcjonowania szarej strefy}

Problem skutków szarej strefy jest wieloaspektowy, a jego jednoznaczna ocena bywa złożona. Jedna część badaczy przyjmuje, że gospodarka nieobserwowalna negatywnie wpływa na wzrost gospodarczy ${ }^{26}$, zaś druga część przedstawia teoretyczne i empiryczne uzasadnienie, iż występuje pozytywny związek pomiędzy zakresem szarej strefy a wzrostem koniunktury ${ }^{27}$.

$\mathrm{Z}$ punktu widzenia dochodów publicznych nielegalne zatrudnienie jest zjawiskiem przynoszącym ograniczenie wpływów budżetowych. Należy jednak zauważyć, że z drugiej strony wytwarzane nielegalnie dobra i usługi mogą być opodatkowane podatkami pośrednimi (jeśli trafią do legalnego obrotu). ${ }^{28}$ Ponadto zwiększenie zarobków ludności, nawet drogą nieformalną, przyczynia się do wzrostu dochodów, a zatem, do zwiększenia wydatków konsumpcyjnych gospodarstw domowych. ${ }^{29}$ Wzrost zakupu dóbr na rynku lokalnym może zapewnić większą produkcję legalnie wytwarzanych dóbr i usług. Dodatkowy popyt dla drobnych przedsiębiorców może oznaczać nowe miejsca pracy, dające legalne zatrudnienie, wchłaniające częściowo szarą strefę.

Uważa się, że znaczna część dochodów (blisko 70\%) uzyskanych w szarej strefie natychmiast zasila oficjalną gospodarkę, co działa na nią stymulująco. ${ }^{30}$ Wprawdzie fundusze uzyskane z ukrytej gospodarki przeznaczane są na kupno takich społecznie nieproduktywnych artykułów, jak: kosztowności, przedmioty luksusowe, dzieła sztuki czy metale szlachetne. Jednak znaczną część środków przeznacza się także na poprawę standardu mieszkaniowego czy inne inwestycje w gospodarstwach domowych, a więc na usługi budowlano-remontowe, które jako wysoce pracochłonne, dają zatrudnienie kolejnym osobom, przyczyniając się w ten sposób do wzrostu dochodów pozostałej części społeczeństwa. ${ }^{31}$

Jedną z zalet szarej strefy jest rozszerzanie rynku pracy polegające na zwiększeniu liczby marginalnych miejsc pracy o niskiej produktywności i niewielkich wynagrodzeniach, które nie byłyby utworzone $\mathrm{w}$ formalnej sferze gospodarki ${ }^{32}$. Jest to szczególnie istotne w okresie słabej koniunktury, gdyż pozwala neutralizować skutki rosnącego bezrobocia, stymulując równocześnie popyt konsumpcyjny. Korzyścią dla osób zatrudnionych w szarej strefie jest możliwość podniesieniu poziomu życia.

${ }^{26}$ N.V. Loayza, The economics of the informal sector: A simple model and some empirical evidence from Latin America, "Carnegie-Rochester Conference Series on Public Policy" 1996, vol. 45, s. 19.

${ }^{27} \mathrm{R}$. Dell'Anno, What is the relationship between Unofficial and Official Economy? An analysis in Latin American Countries, "Quadernni DSEMS" 2008, No. 23, s. 12.

${ }^{28}$ M. Grabowski (red), Szara strefa $w$ transformacji gospodarki, IBnGR, Gdańsk, 1995, s. 6.

${ }^{29}$ E. Lipiński, Historia powszechnej myśli ekonomicznej do roku 1987, Państwowe Wydawnictwo Naukowe, Warszawa 1981, s. 154.

${ }^{30}$ B.S. Frey, F. Schneider, Ekonomika gospodarki nieformalnej, [w:] A. Karwińska, A.Surdeja (red.), Wokót zagadnień gospodarki nieformalnej, Wydawnictwo AE w Krakowie, Kraków 2004, s. 24.

31 P. Kozłowski, Gospodarka nieformalna $w$ Polsce. Dynamika $i$ funkcje instytucji, Instytut Nauk Ekonomicznych, Polska Akademia Nauk, Warszawa 2004, s. 24.

${ }^{32}$ Metodologia badań szarej strefy na rynku ustug turystycznych, red. T. Smuga, Instytut Koniunktury i Cen Handlu Zagranicznego, Warszawa 2005, s.14-15. 
W przypadku osób o niskich kwalifikacjach, które nie miałyby szans na legalne zatrudnienie, może to być jedyny sposób na zmniejszenie zagrożenia ubóstwem dla całej rodziny.

Nielegalne zatrudnienie, jako element szarej strefy, może oznaczać także pozytywne skutki dla pracodawcy, gdyż zwiększa elastyczność godzin pracy i niezależność zatrudnienia, które nie jest skrępowane przepisami prawa. Nielegalny rynek pracy może być odpowiedzią na zbyt wysokie bariery wejścia (zatrudnienia) i/lub wyjścia (zwolnienia) postawione przed pracodawcą. Korzyścią dla pracodawcy jest także obniżenie kosztów pracy, który nie musi odprowadzać podatków i składek na ubezpieczenie społeczne.

\section{Skutki szarej strefy w ocenie podmiotów gospodarczych i gospodarstw domowych}

W celu dokonania identyfikacji skutków szarej strefy wśród przedsiębiorców i gospodarstw domowych w ujęciu subiektywnym zapytano ich, w ramach własnych badań ankietowych, o to, jaki wpływ ma szara strefa na gospodarkę. Strukturę odpowiedzi na to pytanie przedstawia kolejno Rysunek 2. oraz Rysunek 3. Badania ankietowe przeprowadzono na celowej próbie w latach 2010-2019. W kwietniu i maju 2010 roku brało w nich udział 1084 gospod. dom. i 250 podmiotów gosp., w 2011 roku 1201 gospod. dom. i 281 podm. gosp., w styczniu 2012 roku - 1230 gospod. dom. i 232 podm. gosp., w styczniu 2013 roku - 1128 gospod. dom. i 237 podm. gosp., w styczniu 2014 roku - 857 gospod. dom. i 188 podm. gosp., w styczniu 2015 roku - 852 gospod. dom. i 244 podm. gosp., w styczniu 2016 roku - 1103 gospod. dom. i 325 podm. gosp., w styczniu 2017 roku - 1038 gospod. dom. i 289 podm. gosp., w styczniu 2018 roku 883 gospod. dom. i 225 podm. gosp. oraz w styczniu 2019 roku - 975 gospod. dom. i 268 podm. gosp. Wywiady zostały przeprowadzone na terenie województwa podkarpackiego. Ankiety były skierowane do podmiotów $\mathrm{z}$ sektora MSP o zróżnicowanym poziomie obrotów, liczbie zatrudnionych pracowników i okresie funkcjonowania na rynku oraz osób powyżej 20. roku życia o zróżnicowanym poziomie dochodów oraz standardzie życia.

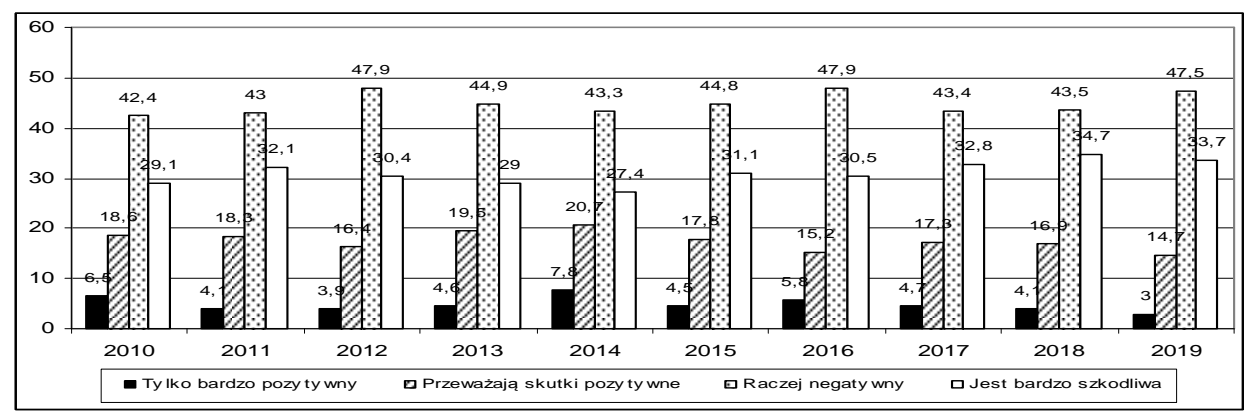

Rysunek 2. Struktura odpowiedzi gospodarstw dom. na pytanie: Jaki wptyw na gospodarke ma szara strefa? (w \%)

Źródło: Obliczenia własne na podstawie badań ankietowych przeprowadzonych wśród gospodarstw domowych w latach $2010-2019$. 


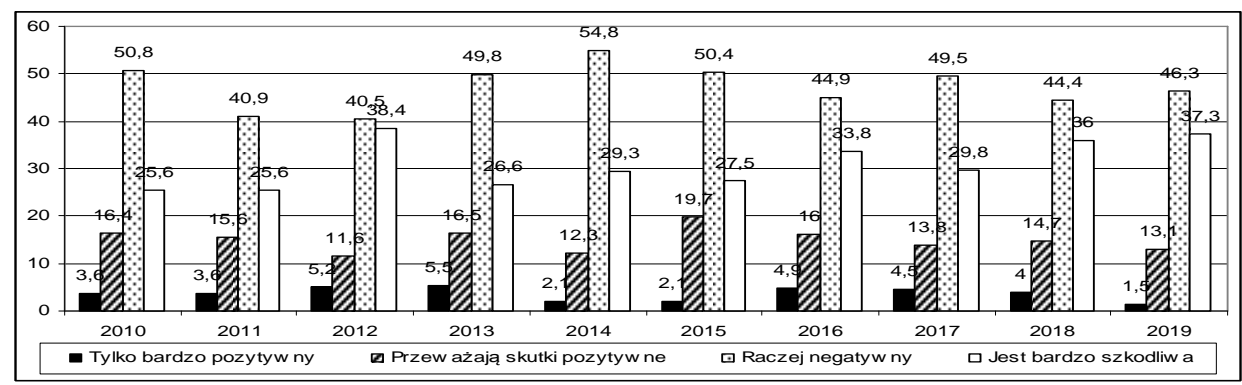

Rysunek 3. Struktura odpowiedzi podmiotów gospod. na pytanie: Jaki wpływ na gospodarkę ma szara strefa? (w \%)

Źródło: Obliczenia własne na podstawie badań ankietowych przeprowadzonych wśród podmiotów gospodarczych w latach 2010 - 2019.

Odpowiedzi respondentów świadczą o tym, iż w ocenie społecznej przeważają skutki negatywne szarej strefy. W każdym roku badania blisko połowa ankietowanych uznała, że badane zjawisko ma raczej negatywny wpływ na gospodarkę $(47,5 \%$ gospodarstw domowych i 46,3\% przedsiębiorców w 2019 r.), a co trzecia osoba wskazywała, że szara strefa jest bardzo szkodliwa dla gospodarki (33,7\% gospodarstw domowych i 37,3\% przedsiębiorców w 2019 r.).

Samych pozytywnych konsekwencji szarej strefy dopatrywało się od 3,0 do 7,8\% gospodarstw domowych oraz 2,1 do $5,5 \%$ przedsiębiorców. Na przewagę skutków pozytywnych częściej wskazywały gospodarstwa domowe od 14,7\% w 2019 r. do 20,7\% w 2014 r. Przedsiębiorcy, którzy częściej borykają się z nielegalną konkurencją ze strony szarej gospodarki rzadziej byli skłonni wybrać ten wariant odpowiedzi (od 11,6\% w 2012 r. do $19,7 \%$ w 2015 r).

Tabela 1. Struktura odpowiedzi gospodarstw domowych na pytanie: Jakie sa najistotniejsze skutki wywotywane przez zjawisko szarej strefy?

\begin{tabular}{|c|c|c|c|c|c|c|c|c|c|c|}
\hline \multirow{2}{*}{ Opinie } & \multicolumn{10}{|c|}{ Struktura procentowa } \\
\cline { 2 - 12 } & 2010 & 2011 & 2012 & 2013 & 2014 & 2015 & 2016 & 2017 & 2018 & 2019 \\
\hline $\begin{array}{c}\text { ogranicza dochody } \\
\text { budżetowe }\end{array}$ & 50,6 & 36,8 & 36,2 & 37,9 & 38,5 & 36,3 & 33,7 & 36,9 & 39,3 & 38,6 \\
\hline $\begin{array}{c}\text { tworzy nowe miejsca } \\
\text { pracy }\end{array}$ & 12,8 & 14,1 & 14,6 & 16,0 & 17,7 & 15,4 & 15,1 & 11,5 & 10,2 & 12,8 \\
\hline $\begin{array}{c}\text { zwiększa dochody } \\
\text { ludności }\end{array}$ & 14,6 & 16,4 & 15,9 & 17,5 & 16,7 & 17,0 & 19,3 & 14,2 & 14,7 & 17,1 \\
\hline $\begin{array}{c}\text { zmniejsza dochody } \\
\text { ludności }\end{array}$ & 7,6 & 9,9 & 8,5 & 8,4 & 7,4 & 8,2 & 13,4 & 11,7 & 10,5 & 5,4 \\
\hline $\begin{array}{c}\text { wymusza podwyżki } \\
\text { podatków }\end{array}$ & 5,9 & 12,7 & 11,7 & 9,4 & 10,4 & 11,5 & 7,9 & 12,2 & 12,8 & 13,3 \\
\hline $\begin{array}{c}\text { powoduje złe } \\
\text { adresowanie pomocy } \\
\text { socjalnej }\end{array}$ & 4,1 & 7,6 & 10,6 & 9,3 & 9,1 & 10,7 & 8,9 & 12,4 & 12,0 & 12,2 \\
\hline inne & 0,4 & 0,1 & 0,6 & 0,2 & 0,2 & 0,5 & 0,4 & 0,5 & 0,3 & 0,1 \\
\hline brak odpowiedzi & 4,0 & 2,4 & 2,0 & 0,3 & 0,0 & 0,5 & 0,7 & 0,7 & 0,1 & 0,4 \\
\hline
\end{tabular}

Źródło: Obliczenia własne na podstawie badań ankietowych przeprowadzonych wśród gospodarstw domowych w latach 2010 - 2019. 
Tabela 2. Struktura odpowiedzi przedsiębiorców na pytanie: Jakie sa najistotniejsze skutki wywoływane przez zjawisko szarej strefy?

\begin{tabular}{|c|c|c|c|c|c|c|c|c|c|c|}
\hline \multirow{2}{*}{ Opinie } & \multicolumn{9}{|c|}{ Struktura procentowa } \\
\cline { 2 - 12 } & 2010 & 2011 & 2012 & 2013 & 2014 & 2015 & 2016 & 2017 & 2018 & 2019 \\
\hline ogranicza dochody budżetowe & 47,2 & 38,0 & 44,8 & 38,4 & 37,8 & 41,0 & 33,2 & 33,6 & 4 & 42,5 \\
\hline tworzy nowe miejsca pracy & 32,8 & 12,4 & 10,8 & 11,4 & 15,4 & 13,1 & 12,9 & 9,7 & 8,0 & 6,7 \\
\hline $\begin{array}{c}\text { zwiększa zyski podmiotów } \\
\text { gospod }\end{array}$ & 25,2 & 7,8 & 6,0 & 8,0 & 16,0 & 9,4 & 14,2 & 10,0 & 9,3 & 11,9 \\
\hline $\begin{array}{c}\text { zmniejsza zyski podm. } \\
\text { gospod. }\end{array}$ & 18,0 & 9,3 & 9,1 & 8,0 & 7,4 & 7,8 & 8,6 & 8,3 & 9,8 & 7,8 \\
\hline wymusza podwyżki podatków & 35,2 & 11,0 & 8,2 & 11,4 & 8,5 & 9,4 & 12,3 & 13,5 & 12,4 & 6,3 \\
\hline $\begin{array}{c}\text { uelastycznia zatrudnienie } \\
\text { powoduje złe adresowanie } \\
\text { pomocy socjalnej }\end{array}$ & 12,0 & 3,8 & 3,0 & 2,5 & 3,2 & 4,1 & 5,5 & 2,8 & 7,1 & 4,1 \\
\hline $\begin{array}{c}\text { Zwiększa ,niezdrową" } \\
\text { konkurencję wśród firm }\end{array}$ & 27,6 & 6,7 & 6,7 & 13,1 & 5,3 & 8,6 & 8,9 & 13,1 & 17,3 & 10,8 \\
\hline inne & 0,4 & 0 & 0 & 0,4 & 0 & 0 & 0 & 1,4 & 0 & 0,7 \\
\hline brak odpowiedzi & 2,4 & 4,1 & 3,0 & 1,3 & 2,7 & 0,8 & 0,3 & 1,7 & 1,8 & 0,8 \\
\hline
\end{tabular}

Źródło: Obliczenia własne na podstawie badań ankietowych przeprowadzonych wśród podmiotów gospodarczych w latach $2010-2019$.

Tabele 1. i 2. prezentują strukturę odpowiedzi na pytanie o najistotniejsze skutki wywoływane przez szarą strefę. Najczęściej respondenci wskazywali na ograniczenie dochodów budżetowych, które są konsekwencją oszust podatkowych $(38,6 \%$ gospodarstw oraz 42,5\% przedsiębiorców w 2019 r. wybrało ten wariant odpowiedzi). Niemniej jednak blisko co dziesiąta osoba zwróciła uwagę, iż pomimo wskazywanych wad, szara strefa tworzy nowe miejsca pracy, co w okresach gorszej koniunktury gospodarczej pozwala łagodzić problem bezrobocia. Zarówno osoby fizyczne, jak i prawne były zdania, iż $\mathrm{w}$ odniesieniu do indywidualnych dochodów, szara strefa wpływa na zwiększenie zarobków gospodarstw domowych oraz zysków podmiotów gospodarczych (w 2019 r. - 17,1\% gospodarstw oraz 11,9\% przedsiębiorców). W ostatnich latach zwiększyło się też przekonanie, iż szara ukryte dochody szarej strefy powodują złe adresowanie pomocy socjalnej.

Pomimo, wydawać by się mogło, zdecydowanego przekonania większości osób biorących udział $\mathrm{w}$ badaniu, o negatywnych skutkach jakie niesie za sobą szara strefa dla gospodarki. W odniesieniu do indywidualnej sytuacji gospodarstw domowych i przedsiębiorstw dopatrywano się także cech pozytywnych, takich jak możliwość podwyższenia legalnego dochodu lub zysku, czy zwiększenie możliwości zarobkowych poprzez uelastycznienie zatrudnienia. Równocześnie blisko co dziesiąty przedsiębiorca zawracał uwagę na zakłócenie mechanizmów konkurencji ze strony nielegalnie działających podmiotów.

\section{Działania instytucjonalne ograniczające rozmiary szarej strefy w Polsce}

W Polsce najskuteczniejsze działania prowadzące do ograniczania rozmiarów, a zarazem skutków gospodarki nieobserwowalnej odbywają się w trzech, na ogół nie powiązanych ze sobą obszarach. Pierwszy to działania nastawione na odzyskiwanie traconych 
należności podatkowych (legislacyjne, kontrolne, represyjne). Kolejny to edukacja i prewencja podejmowana przez organy administracji państwowej (przykładem może być wprowadzona w czwartym kwartale 2015 r. Loteria paragonowa ${ }^{33}$, która skłania podatników do domagania się od sprzedawców i usługodawców paragonów fiskalnych, potwierdzających opłacenie VAT).

Trzecim obszarem, a zarazem skuteczną i sprawdzoną w wielu państwach metodą jest propagowanie i rozwój obrotu bezgotówkowego. Wynika to z faktu, iż transakcje w szarej strefie przeprowadzane są niemal wyłącznie z wykorzystaniem gotówki, dzięki czemu nie pozostawiają ,śladów” na podstawie których można stwierdzić niezgodności. Rozszerzanie obrotu bezgotówkowego następuje w Polsce od początku transformacji gospodarczej, ale w ostatnich kilku latach daje się zauważyć intensyfikację tego procesu. Dzieje się tak za sprawą rewolucyjnego postępu technologicznego w tym zakresie połączonego z wdrażaniem tych rozwiązań przez polski system bankowy, np. płatności przy pomocy urządzeń mobilnych, płatności zbliżeniowe bez autoryzacji kodem PIN. Innych czynnikiem przyśpieszającym obrót bezgotówkowy było obniżenie prowizji za obsługę terminali płatniczych dla przedsiębiorców, umożliwienie dokonywania tego typu transakcji w urzędach miast i gmin, obligatoryjne wymuszenie wypłat wynagrodzeń sfery budżetowej poprzez konta bankowe.

Kolejnym elementem wdrożonym przez Ministerstwo Finansów w ramach szerzenia praktyki rzetelnego i legalnego obrotu gospodarczego było obniżenie progu płatności gotówkowych. Zgodnie z ustawą o swobodzie działalności gospodarczej od stycznia 2017 roku obowiązuje górny limit 15000 PLN dla płatności gotówkowych w obrocie gospodarczym (poprzednio limit ten wynosił 15000 euro) - art. 22 ust. 1. ustawy z dnia 2 lipca 2004 r. o swobodzie działalności gospodarczej (Dz. U. z 2016 r. poz. 1829 z późn. zm). Wprowadzenie takiej regulacji ma na celu ograniczenie zjawiska prania brudnych pieniędzy pochodzących z szarej strefy i wydaje się, że w praktyce faktury dokumentujące transakcje o podobnej wartości regulowane w formie gotówkowej, z wysokim prawdopodobieństwem mogły mieć charakter fikcyjny.

Należy podkreślić, iż wprowadzona zmiana $\mathrm{z}$ punktu widzenia budżetu państwa może mieć charakter pozytywny, gdyż będzie $w$ stanie przyczynić się do efektywniejszego ograniczania szarej strefy, szczególnie mającej znamiona oszust podatkowych. Może też pomóc organom skarbowym skuteczniej egzekwować zobowiązania publicznoprawne oraz w konsekwencji zwiększyć wpływy podatkowe ${ }^{34}$.

Istotną modyfikacją ukierunkowaną na walkę z szarą strefą jest przekształcenie służb kontroli skarbowej oraz służb celnych w Krajową Administrację Skarbową (1 marca 2017 r.). Dzięki nowej instytucji nastąpiła efektywniejsza wymiana danych, konsolidacja i koordynacja kontroli, a także bardziej efektywne planowane i realizacja działań nakierowanych na ograniczanie szarej strefy. $Z$ danych przedstawionych przez Ministerstwo Finansów wynika, że urzędnicy skarbowi stali się bardziej skuteczni i lepiej przygotowani - w I półroczu 2018 r. znacząco wzrosła efektywność kontroli przy

\footnotetext{
${ }^{33}$ Narodowa Loteria Paragonowa wprowadzona została w październiku 2015 roku i trwała 18 miesięcy, a w jej ramach zarejestrowano ponad 137 milionów paragonów fiskalnych. Przeciwdziałanie szarej strefie w Polsce poprzez efektywny wymiar sprawiedliwości, UN Global Compact, Warszawa 2017, s. 75.

${ }^{34}$ A. Ćwikała-Małys, I. Piotrowska, Obniżenie limitu płatności gotówkowych jako element efektywnego ograniczania szarej strefy w Polsce, Prace Naukowe Uniwersytetu Wrocławskiego, nr 480, Wrocław 2017, s. 40 i nast.
} 
jednoczesnym spadku ich liczby ${ }^{35}$. Stało się tak dzięki konsekwentnemu przenoszeniu ciężaru walki z nieprawidłowościami podatkowymi na etap analizy danych, planowania i typowania kontroli. Tradycyjna kontrola prowadzona w siedzibie przedsiębiorstwa jest tylko zwieńczeniem całego procesu ${ }^{36}$.

Na poprawę efektywności urzędników skarbowych mogło mieć wpływ wdrożenie 1 lipca 2016 r. Jednolitego Pliku Kontrolnego (JPK), który pomaga minimalizować przede wszystkim potencjalne nieprawidłowości $\mathrm{w}$ podatku $\mathrm{VAT}^{37}$. JPK to obligatoryjne raportowanie organom skarbowym o szczegółach wszystkich faktur, $\mathrm{z}$ jakimi przedsiębiorstwo ma do czynienia. Początkowo wymóg ten dotyczył jedynie dużych przedsiębiorstw, natomiast od 1 stycznia 2018 r. objął już wszystkich podatników. Informacje zawarte w plikach JPK_VAT wykorzystywane były łącznie w 5,6\% kontroli rozliczeń podatku VAT przeprowadzonych przez urzędy skarbowe w okresie 2017-I połowa $2018 \mathrm{r}$. W wyniku kontroli ujawniono nieprawidłowości na kwotę 266,9 mln zł. ${ }^{38}$

W ramach reform prawa gospodarczego zawartych w Konstytucji Biznesu zaproponowano małym przedsiębiorcom rozwiązanie mające skłonić ich do wyjścia z szarej strefy. Jest nim tzw. działalność nierejestrowana, która zaczęła obowiązywać 30 kwietnia 2018 r. $^{39}$ Działalność nierejestrowana jest propozycją skierowaną do drobnych usługodawców, działających na małą skalę np. prowadzących korepetycje, świadczących drobne usługi krawieckie, czy innych osób dla których działalność gospodarcza ma charakter dorywczy. Najczęściej takie podmioty funkcjonują w szarej strefie, gdyż przy ich niskich dochodach z okazjonalnej aktywności, nie zawsze opłaca im się ewidencjonować działalność. Nowe rozwiązanie umożliwia takim osobom prowadzenie drobnej działalności zarobkowej (przychód nie przekraczający 50\% minimalnego wynagrodzenia, tj. 1125 zł w 2019 r.) bez rejestracji w Centralnej Ewidencji i Informacji o Działalności Gospodarczej. Osoby te nie będą także podlegać obowiązkowi ubezpieczeń społecznych. Jednak istnieje obawa, iż narzędzie to, mające zachęcać do legalizacji aktywności gospodarczej może przewrotnie do niej motywować. Osoby takie prowadząc minimalną ewidencję zdarzeń gospodarczych (ewidencja sprzedaży) mogą dalej być skłonne tak zaniżać przychody, aby nie przekroczyć wymaganego ustawowego progu uprawniającego je do zwolnienia ze składek ZUS.

\section{Podsumowanie}

Krajowe oraz międzynarodowe szacunki szarej strefy w Polsce prezentują tendencję malejącą opisywanego zjawiska. Według Głównego Urzędu Statystycznego gospodarka nieobserwowalna w Polsce zmniejszyła się z 17,2\% PKB w 1994 r. do 13,2\% PKB

\footnotetext{
35 W pierwszym półroczu 2018 r. urzędy celno-skarbowe przeprowadziły łącznie 1700 kontroli, ustalając zobowiązania podatkowe na kwotę 6,40 mld zł, wobec 2633 kontroli zakończonych ustaleniami na łączna kwotę 7,44 mld zł w analogicznym okresie 2017 r. W konsekwencji średnia kwota ustaleń na jedną kontrolę wyniosła 3,55 mln zł w 2018 r, a w 2017 r. - 2,82 mln zł. Por. Raport Bezpieczny podatnik. Pod lupa fiskusa, AXA, YE, Warszawa grudzień 2018, s.6.

${ }^{36}$ Raport Bezpieczny podatnik. Pod lupa fiskusa, AXA, YE, Warszawa grudzień 2018

${ }^{37}$ Ustawa z dnia 13 maja 2016 r. o zmianie ustawy - Ordynacja podatkowa oraz niektórych innych ustaw, Dz. U. 2016 poz. 846

${ }^{38}$ Wykorzystanie Jednolitego Pliku Kontrolnego w postępowaniach i kontrolach podatkowych, Najwyższa Izba Kontroli, Warszawa sierpień 2019, s.10; gov.pl/plik/id,21158,vp,23790.pdf

${ }^{39}$ Ustawa z dnia 6 marca 2018 r. - Prawo przedsiębiorców, Dz.U. 2018 poz.646.
} 
w 2016 r. W ocenia F. Schneidera w porównaniu z 2000 rokiem skala szarej strefy skurczyła się z 27,6\% do 22,2\% PKB w 2017 roku. Mimo tendencji spadkowej rozmiary gospodarki nieobserwowalnej w wartościach nominalnych w dalszym ciągu są ogromne. Zgodnie z szacunkami Instytut Prognoz i Analiz Gospodarczych całkowita wartość szarej strefy w 2019 roku wyniesie 242 mld PLN, co stanowić będzie 17,2\% PKB (w 2016 r. - 19,0\%, 2017 r. - 18,7\% PKB, w 2018 r. - 18,0\%).

Szara strefa uznawana jest za zjawisko wielowymiarowe, mające wpływ na wiele aspektów życia społecznego i gospodarczego. Przeważają konsekwencje negatywne takiej jak zaniżanie wpływów podatkowych, fałszowanie statystyk, błędna alokacja pomocy społecznej, czy zakłócanie mechanizmów konkurencji. Niemniej jednak szara strefa charakteryzuje się też następującymi walorami: łagodzenie następstw stagnacji gospodarczej, tworzenie tanich miejsc pracy dla tzw. marginalnej siły roboczej, tworząc dodatkowe źródła dochodów dla gospodarstw domowych.

Wydaje się, że także w ocenie społecznej dominują skutki negatywne szarej strefy w odniesieniu do wpływu na gospodarkę krajową, o czym świadczą badania ankietowe przeprowadzone w latach 2010-2019. Około 80\% gospodarstw domowych biorących udział w badaniu wskazywało, iż szara strefa jest bardzo szkodliwa dla gospodarki albo raczej negatywna, poza paroma korzyściami. Jedynie co piąte gospodarstwo domowe i zaledwie kilkanaście procent przedsiębiorców widziało jedynie zalety w fakcie występowania gospodarki nieobserwowalnej. Pomimo, iż ankietowali dostrzegali zdecydowanie negatywne konsekwencje w odniesieniu do gospodarki, to z perspektywy najistotniejszych skutków szarej strefy w ujęciu bardziej indywidualnym ankietowani potrafili wskazać także korzyści badanego zjawiska, takie jak źródła dodatkowych dochodów i zysków bądź rozszerzenie oraz uelastycznienie rynku pracy.

Analiza danych statystycznych w ostatnich latach pokazuje stopniowe i powolne obniżanie się udziału szarej strefy w produkcie krajowym brutto. Jest to efektem kilku czynników: poprawiającej się koniunktury gospodarczej, zdecydowanych działań władz nakierowanych na uszczelnienie systemu podatkowego, wprowadzenie nowych regulacji oraz działań na rzecz promocji obrotu bezgotówkowego. Pozytywnie należy ocenić także konsolidację w administracji celno-skarbowej, która umożliwiła koordynację działania wszystkich służb, a dzięeki temu poprawę efektywności kontroli. Równocześnie pojawiają się też symptomy zwiększania aktywności w szarej strefie za sprawą niektórych rozwiązań prawnych, jak np. programu Rodzina $500+{ }^{40}$. Kwestią sporną jest także tak zwana działalność nierejestrowana, która w założeniu miała ograniczać szarą strefę, a docelowo może okazać się jej bodźcem. Wydaje się, ze najlepsze rezultaty będą przynosić działania systemowe nakierowane na łagodzenie różnych ograniczeń nakładanych na przedsiębiorstwa niż działania represyjne.

Jednoznaczna ocena skutków gospodarki nieformalnej jest niesłychanie trudna i różnić się będzie w zależności od konkretnego rodzaju nieoficjalnej aktywności ekonomicznej. Zróżnicowane też powinno być podejście rządu i administracji gospodarczej do poszczególnych jej przejawów i obszarów. Nie ulega wątpliwości, że podziemie gospodarcze powinno być energicznie zwalczane, podczas gdy np.

${ }^{40}$ M. Pasternak-Malicka, The impact of social transfers on the tendency of women in Poland to take up employment in the gray economy, Prace Naukowe Uniwersytetu Ekonomicznego we Wrocławiu vol. $63 \mathrm{nr} 8$, Wydawnictwo UW, Wrocław 2019, s. 128-142. 
w odniesieniu do samozaopatrzenia gospodarstw domowych (wyrób produktów na własne potrzeby, pomoc sąsiedzka) można byłoby oczekiwać co najmniej życzliwej neutralności. Warto jednak podkreślić, ze wymienione pozytywne aspekty funkcjonowania szarej strefy działają efektywnie w krótkim czasie. Rozszerzanie zakresu nieoficjalnej gospodarki może natomiast doprowadzić do nasilenia się negatywnych skutków w długim okresie.

\section{Bibliografia}

Balcerowicz L., Socjalizm, kapitalizm, transformacja, Szkice z przełomu epok, PWN, Warszawa 1997.

Cassel D., Caspers A., Was ist Schattenwirtschaft? Begriff und Erscheinungsformen der Sekond Economy, Wisrtschaftswissenschaftliches Studium, Heft 1, 1984, s. 1-7.

Chrościcki T., Misiak M., Szara strefa, „Nasz Rynek Kapitałowy”, nr 10, październik 2005, s. 66.

Ćwikała-Małys A., Piotrowska I., Obniżenie limitu płatności gotówkowych jako element efektywnego ograniczania szarej strefy w Polsce, Prace Naukowe Uniwersytetu Wrocławskiego, nr 480, Wrocław 2017, s. 40 i nast.

Dell'Anno R., What is the relationship between Unofficial and Official Economy? An analysis in Latin American Countries, "Quadernni DSEMS" 2008, No. 23, s. 12.

Dzierżawski K., Krótki kurs ekonomii praktycznej, Wydawnictwo Zysk I Spółka, Warszawa 2006, s. 85 .

Elgin C., Uras B.R., Public debt, sovereign default risk and shadow economy, „Journal of Financial Stobility", Np 9, 2013, s. 19

Feige E.L., The underground economy. Tax evasion and information distortion, Cambridge University Press, 1989, s. 2.

Frey B.S., Schneider F., Ekonomika gospodarki nieformalnej, [w:] A. Karwińska, A.Surdeja (red.), Wokót zagadnień gospodarki nieformalnej, Wydawnictwo AE w Krakowie, Kraków 2004, s.15.

Fundowicz J., Łapiński K., Wyżnikiewicz B., Wyżnikiewicz D., Szara strefa 2019, Instytut

Prognoz i Analiz Gospodarczych, Warszawa marzec 2019, s. 24.

Fundowicz J., Łapiński K., Wyżnikiewicz B.,, Szara strefa 2018, Instytut Prognoz i Analiz

Gospodarczych, Warszawa marzec 2018, s. 9

Grabowski M. (red), Szara strefa w transformacji gospodarki, IBnGR, Gdańsk, 1995, s. 6.

Górka K., Łuszczyk M., Gospodarka nieobserwowalna w Polsce i na świecie, Studia i Prace Wydzialu Nauk Ekonomicznych i Zarządzania, Uniwersytet Szczeciński, nr 41, t. 2. 2015. DOI:10.18276/SIP.2015.44/2-19

Herrer W., Sadowski W., Wptyw „szarej strefy” na makroproporcje gospodarki narodowej, [w:] Szara gospodarka w Polsce. Rozmiary, przyczyny, konsekwencje, Zakład Badań Statystyczno-Ekonomicznych GUS i PAN, z. 233, Warszawa 1996, s. 34-35.

Kowalik T. (red.), Nierówni i równiejsi, Fundacja Innowacja, Warszawa 2002, s. 226.

Kozłowski P., Gospodarka nieformalna w Polsce. Dynamika i funkcje instytucji, Instytut Nauk Ekonomicznych, Polska Akademia Nauk, Warszawa 2004, s. 24.

Lipiński E., Historia powszechnej myśli ekonomicznej do roku 1987, Państwowe Wydawnictwo Naukowe, Warszawa 1981, s. 154.

Loayza N.V., The economics of the informal sector: A simple model and some empirical evidence from Latin America, "Carnegie-Rochester Conference Series on Public Policy" 1996, vol. 45.

Martinez J.C., La fraude fiscale, Paris 1984, s. 11. [Za:] M. Kalinowski, Granice legalności unikania opodatkowania w polskim systemie podatkowym, TNOiK, Torun 2001, s. 24.

Medina L., Schneider F., Shadow Economies Around the World: What Did We Learn Over the Last 20 Years?, WP/18/17, International Monetary Fund, Styczeń 2018, s. 18, 66 i nast. 
Metodologia badań szarej strefy na rynku ustug turystycznych, red. T. Smuga, Instytut

Koniunktury i Cen Handlu Zagranicznego, Warszawa 2005

Mróz B., Metody pomiaru gospodarki nieoficjalnej, „Ekonomista”, nr 1, 2001, s. 93.

Pasternak-Malicka M., The impact of social transfers on the tendency of women in Poland to take up employment in the gray economy, Prace Naukowe Uniwersytetu Ekonomicznego we Wrocławiu vol. $63 \mathrm{nr}$ 8, Wydawnictwo UW, Wrocław 2019, s. 128-142.

Piecuch T., Szczygieł E., Przedsiębiorczość szarej strefy, „Roczniki Ekonomii i Zarządzania”, Tom 10 (46), nr 2, 2018. DOI:http://dx.doi.org/10.18290/reiz.2018.10.2-6

Pozo S., Exploring the Underground Economy. Studies of Illegal and Unreported Activity, W.E. Upjohn Institute for Employment Research, Kalamazoo 1996, s. 156.

Przeciwdziałanie szarej strefie w Polsce poprzez efektywny wymiar sprawiedliwości, UN Global Compact, Warszawa 2017, s. 75.

Rachunki narodowe wedtug sektorów i podsektorów instytucjonalnych w latach 2012-2015, GUS, Warszawa 2017, s. 267.

Rachunki narodowe wedtug sektorów i podsektorów instytucjonalnych w latach 2013-2016, GUS, Warszawa 2018, s. 281 i nast.

Rajewski Z., Zienkowski L., Szara gospodarka w systemie rachunków narodowych, [w:] Szara gospodarka $w$ Polsce. Rozmiary, przyczyny, konsekwencje, ZBSE GUS i PAN, Zeszyt 233, Warszawa 1996, s. 13.

Raport Bezpieczny podatnik. Pod lupa fiskusa, AXA, YE, Warszawa grudzień 2018, s.6.

Schneider F., Buehn A., Shadow Economy: Estimation Methods, Problems, Results and Open questions, Open Economics 2018, 1:1-29, s. 22; DOI 10,1515/openec-2017-0001

Schneider F., Williams C., The Shadow Economy, Institute of Economic Affairs, Profile Books, Ltd. - Hobbs the Printers, London 2013, s. 25.

Stiglitz J.E., Ekonomia sektora publicznego, PWN, Warszawa 2010, s. 854.

Szarek S., Okliński D., Czynniki wptywające na akceptację szarej strefy w spoteczeństwie, Zeszyt

Naukowe Uniwersytetu Przyrodniczo-Humanistycznego w Siedlcach, Seria Administracja I

Zarządzanie, nr 109/2016, s.94.

Świątkowski A., Międzynarodowa polityka społeczna wobec świadczacych pracę $w$ nieformalnej gospodarce, „Polityka Społeczna”, nr 4, 2003, s. 2.

Ustawa z dnia 13 maja 2016 r. o zmianie ustawy - Ordynacja podatkowa oraz niektórych innych ustaw, Dz. U. 2016 poz. 846.

Ustawa z dnia 6 marca 2018 r. - Prawo przedsiębiorców, Dz.U. 2018 poz.646

Wykorzystanie Jednolitego Pliku Kontrolnego $w$ postępowaniach $i$ kontrolach podatkowych, Najwyższa Izba Kontroli, Warszawa sierpień 2019, s.10; gov.pl/plik/id,21158,vp,23790.pdf

\section{Summary}

The article addresses the issue of the gray economy. In the first part the definition of the shadow economy in the context of tax evasion and the scale of the phenomenon in Poland are included. The following shows the negative and positive effects of the gray economy listed in the literature on the subject. In the third part fragments of a questionnaire survey were described concerning the problem. In the last part of the article, institutional activities affecting the size of the shadow economy in Poland are presented.

The main purpose of this publication is to present the positive and negative consequences of the shadow economy, understood as tax evasion, and indicate which consequences prevail in the subjective assessment of the surveyed business entities and households. The article also indicates actions aimed at limiting the studied phenomenon. The implementation of the objective required the use of descriptive and statistical methods, in particular analysis of the shape and scope of the unobservable economy in Poland and selected countries. The direct-questionnaire method was also 
used. The article uses fragments of author-conducted study from 2010-2019 in order to make a qualitative attempt to assess the effects of the gray zone phenomenon.

Keywords: gray market, unobservable economy, tax fraud, effects of the gray economy JEL Codes: H21, H24, H26, H83

\section{Informacja o autorze:}

Monika Pasternak-Malicka

Politechnika Rzeszowska

Al. Powstańców Warszawy 12, Rzeszów, Polska

e-mail: malicka@prz.edu.pl

ORCID: 0000-0002-0011-7626 